\title{
Water and sediment yield estimation: A case study in Bawashaswar Watershed/ Iraqi Kurdistan Region
}

\author{
Sarkawt G. Salar ${ }^{1, *}$, Abdulhaq N. Mahmoud ${ }^{2}$, Arsalan A. Othman ${ }^{3,4}$ \\ ${ }^{1}$ Dept. of Geography, College of Education, University of Garmian, \\ ${ }^{2}$ Natural Resources Research Center, University of Tikrit, \\ ${ }^{3}$ Iraq Geological Survey, Baghdad, Iraq; \\ ${ }^{4}$ Komar University of Science and Technology, Sulaymaniyah, 46001, Iraq \\ *Corresponding author: sarkawt.ghazi@garmian.edu.krd
}

\begin{abstract}
Water flow in the seasonal streams forms a vital supplier of water resources, particularly in arid and semiarid areas due to its high water supply from the precipitation during the wet season. This research aims to estimate water and sediment yield in the Bawashaswar watershed (BW), which is far $\sim 90 \mathrm{~km}$ from Kirkuk City and covers an area of $277 \mathrm{~km}^{2}$. The Bawashaswar Dam (BD) was constructed for multi-purposes, such as drinking, irrigation, livestock, and tourism at the outlet of the watershed north of Kifri town. The Soil Water Assessment Tool (SWAT) was integrated with several datasets, such as satellite images, Digital Elevation Model (DEM), land use, land cover, curve number $(\mathrm{CN})$, daily climatic data of temperature, precipitation, and digital soil map to achieve the results. The estimated results include precipitation, evaporation transpiration, percolation, surface runoff, water yield, loss of transport, and sediment yield. The results showed that almost all the siltation ( $>0.5$ ton/ha) comes from the western and northern parts of the BW due to the high topographic relief and the high channel discharge there. These results will support the future development plans and management of the watershed through mitigating and minimizing the size of the ground surface degradation problems all over the study area with increasing the lifespan of the BD.
\end{abstract}

Keywords: Bawashaswar dam; GIS; Kurdistan region; SWAT; sediment yield.

\section{Introduction}

Obtaining accurate information about the rainfall-runoff situation improves the decisionmaking power on the coming plans for the administrators of the watersheds of natural resources for sustainable development (Alipour \& Hosseini, 2018). Watershed is an environment and land management unit (Wang et al., 2016). One of the major problems in watershed management is siltation. Therefore, forecasting the soil and valleys' erosion is a significant matter in the estimation of land landscape studies and management strategies (Liu et al., 2015).

The hydraulic structures, such as dams and weirs, need better management to control deposition and siltation upstream of their outlets (Amin et al., 2019). In some cases, it can be hazardous to human settlements and engineering facilities located near rivers or streams downstream of the dams, like that, happened at the BD in the present study area. Hydrological models are utilized as simulation models to assess water availability, several managing states 
of harvesting, and to appraise its influence on water property (Krishnan et al., 2018). The SWAT model can assume sediment load and deposition employing a spatial and temporal distribution strategy (Afshar \& Hassanzadeh, 2017).

Several articles applied the SWAT model to calculate the components of the basins at various climatic conditions in different areas and situations. Talebizadeh et al. (2010) stated that the SWAT model is the best for calculating the sediment yield compared to the Artificial neural network (ANN) model. Later on, Yu et al. (2011) established runoff simulation by the SWAT model employing various rainfall sources in large dry watersheds with limited rain gauges. Mosbahi et al. (2012) reported several elements and functions for simulating water balance, sediment loss, climate change, crop growing, and ground management practices. Woznicki \& Nejadhashemi (2013) demonstrated the SWAT model is very useful in sediment yield estimation and identification of the best site for Best Management Practices (BMPs) to reduce the sediment delivery ratio. According to Krysanova \& White (2015), the model's common uses have confirmed its ability to simulate long-term environmental influences under various climatic conditions for watershed management varies from small, medium, and large watersheds.

Yesuf et al. (2016) affirmed that the employment of short-term and long-term data in the watershed models is significant to predict the hydrological behavior of the stream channels within the watershed. Fallah et al. (2016) used the model to recognize the erodible areas in the Haraz sub-basins. Duan et al. (2017) evaluated the influences of probable future climate change scenarios of the upper reaches of the Ishikari River basin. Othman et al. (2021) used RUSLE equations and sub-basins size to calculate the sediment yield in the Khabour River Basin.

In this context, the SWAT model was employed in the BW to estimate water and sediment yield. BW is one of the waters and sediment yield-prone watersheds in the Iraqi Kurdistan Region due to its geologic, geomorphic, and climatic situation. According to the field observations, a large amount of water and sediments are produced and entered into the watershed through the mainstream branches. This huge amount of water and sediment yield are deposited and filled the dam reservoir on October 29 and 30, 2015. They caused a real problem to the dam's body, which became hazardous to human life in the center of the Kifri district and damaged the agricultural lands downstream. As a consequence, the current study aims to estimate water and sediment yield in the BW. The obtained result will help and enable decisionmakers in (1) a better water resources planning and management; (2) controlling water and soil losses; (3) decreasing the flood risk and dam failure (4) increasing the life span of the BD (5) implementing soil and water conservation practices.

\section{Methods and Materials}

\subsection{The study area}

BW is located $75 \mathrm{~km}$ south of Sulaymaniyah City. It covers $\sim 277 \mathrm{~km}^{2}$ (Figure 1) and has a semiarid climate (Salar, 2006; Al-Umary et al., 2013). Bawashaswar stream represents the mainstream in the study area (Salar, 2009). It mainly supplies the groundwater recharge. The 
surface water and precipitation irrigated the highest amount of the cultivated areas. The people exploited groundwater for drinking and household uses (Al-Kubaisi \& Salar, 2009).

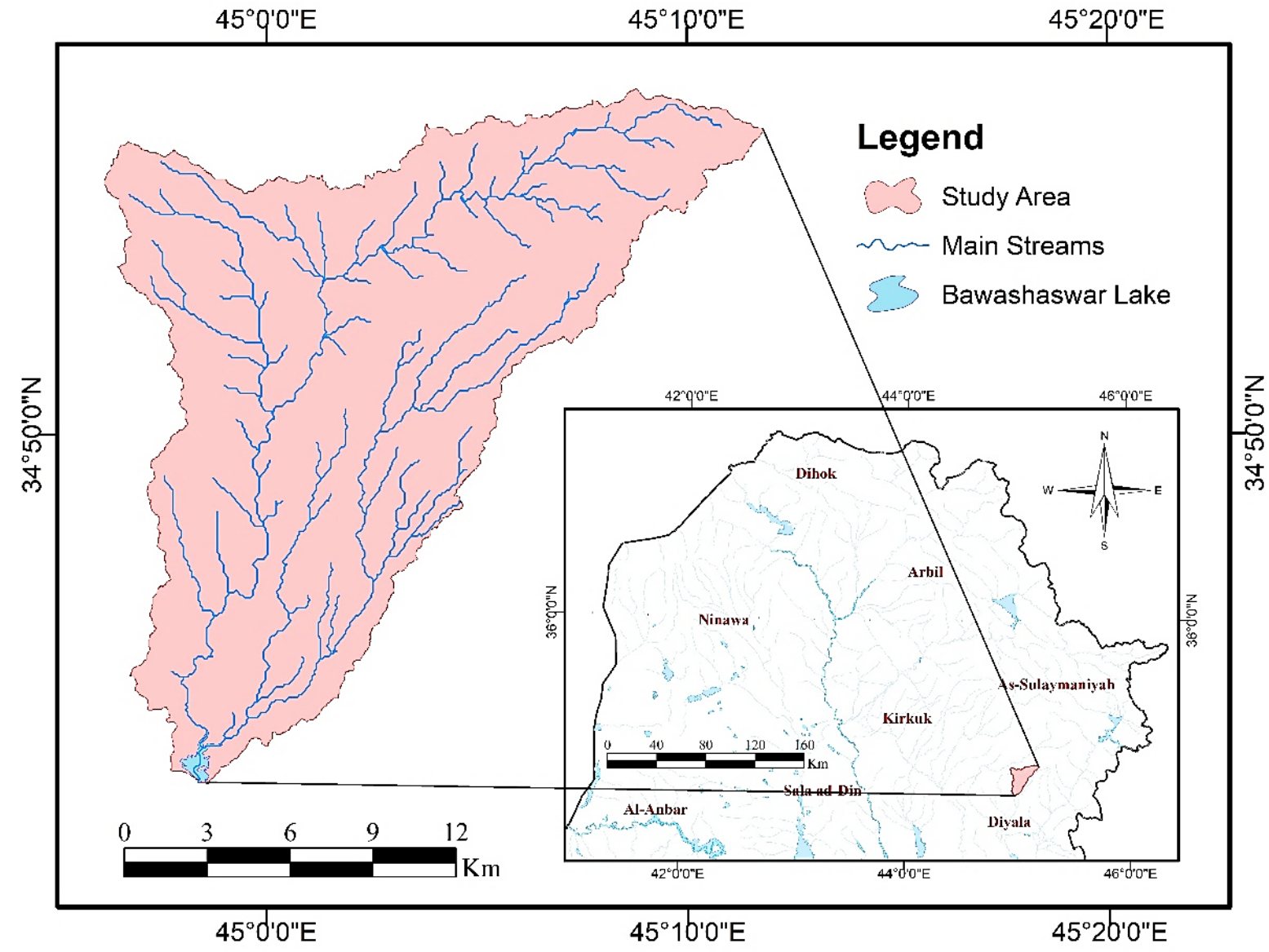

Fig. 1. Location of the BW.

\subsection{Geologic Setting}

The Iraqi tectonic units have resulted from the ongoing subduction of the Arabian Plate beneath the Eurasian Plate (Othman \& Gloaguen, 2013; Othman \& Gloaguen, 2014; Salar et al., 2018; Othman et al., 2018; Othman et al., 2019). The BW lies in the low folded zone of the unstable shelf of the Zagros Orogenic Belt. Structurally, the area presence several geological structures, such as anticline, syncline, thrust faults, and joints. It includes Kifri and Jambur thrust anticlines. They are long, tight, and asymmetrical anticlines isolated by long synclines extending northwest-southeast. Fatha, Injanah, Muqdadiyah, Bai Hassan formations crop out in the study area (Al-Kubaisi \& Salar, 2009). The Fatha Formation (Middle Miocene) composites alternating of gypsum, claystone, marl, and limestone. The Injana Formation (Late Miocene) is mainly composed of alternating bedrocks of claystone, siltstones, and sandstones (Sissakian \& Al-Jiburi, 2012). The Mukdadiyah Formation (Pliocene) encompasses clay, sandstone, and pebbly sandstone. The Bai Hassan Formation (Pliocene) is mostly comprised of conglomerate, sandstone, and claystone. Different types of Quaternary sediments are deposited, such as a floodplain, polygenetic, terraces, and slope sediments. These deposits comprise a wide part of the study area (Salar, 2009). 


\subsection{SWAT Model}

The SWAT model is broadly applied to assess surface runoff and stream loads of a watershed. The sediment load results from the erosion of the landscape by the drainage network (Mukundan \& Pierson, 2015). The main basin is split into many sub-basins with similar hydrologic characteristics (Chowdary et al., 2013).

The current study implemented the AGWA2 (Automated Geospatial Watershed Assessment) tool package as an extension in the ArcGIS environment using geospatial information to recognize stream discharge and erosion in the watershed. It is designed for natural resource and land managers. It includes two models (1) Kinematic Runoff and Erosion (KINEROS2) hydrologic model and (2) SWAT (Figure 2). The SWAT model has been applied in the BW. Meteorological data, soil type, DEM, land-use, and land cover maps are the essential inputs data to the SWAT model (Asl-Rousta et al., 2018). It required daily meteorological data as a main deriving force of water and sediment yield. The study area is lacking daily meteorological data. Hence, the present paper is dependent on the daily meteorological data collected by Kirkuk's station for the last 30 years. The data includes precipitation and minimum-maximum temperature. DEM dataset, with $30 \mathrm{~m}$ cell size, was used to delineate the BW resulting from a grid based on the accumulated flow to the chosen outlet of the BW. Either an individual watershed or a group of watersheds is extracted and separated, and the drainage system extracted and the slope gradient calculated. The soil data from the FAO soil classification map with a scale of 1:5000000 has been collected (FAO-Unesco, 2007). Landuse and the land cover map were derived from Landsat 8 (OLI) multispectral imagery with 30 $\mathrm{m}$ cell size using a spectral interpretation method to assess its impact on hydrology and generate $\mathrm{CN}$ mapping. The evapotranspiration is calculated using Monteith-Penman, Priestley-Taylor, and Hargreaves methods. The Monteith-Penman method depends on solar radiation, temperature, humidity, and wind speed; the Priestley-Taylor method depends on solar radiation, temperature, and humidity; while the Hargreaves method is used air temperature to calculate the evapotranspiration (Kavian et al., 2017). The present study used the SWAT model to estimate precipitation (P), evapotranspiration (ET), percolation (Perc), surface runoff (Surq), water yield (Watyld), sediment yield (SedYld), and sediment concentration (SedCon).

\subsection{Input Parameters}

The required data for the SWAT model used in the BW as input are DEM, meteorological data, soil, land use, and land cover maps (Table 1). The watershed, sub-watersheds, and drainage networks of the Bawashswar were extracted from the DEM. Moreover, some of the geomorphological parameters of the watershed, such as slope for hydrologic response units (HRU) definition have been computed.

This research used the daily precipitation and other required climatic variables (temperature, wind speed, solar radiation, and relative humidity) to estimate water and sediment yield within sub-basins entering the Bawashaswar Lake. Consequently, the obtained precipitation map was a polygon with a single value (Appendix 1). The mean annual precipitation was $\sim 347 \mathrm{~mm}$. Most of the rainfall occurs during October-March, with a peak in December and January (Salar, 2009). 
The type of soil is one of the significant parameters that extensively influence water infiltration because various soil types have different soil textural and physical, and chemical properties (Duan et al., 2017). According to the soil map (Appendix 2), two types of soil appear in the study area; (1) Calcic Xerosols (Xk28-b) soil type, which covers small regions (5\% of the watershed) at the uppermost northeast of the study area. Its slope range between $4.5^{\circ}$ and $19^{\circ}$ (Figure 3b). This type of soil consists of coarse grain particles reflecting lithologic characteristics of bedrocks. the most dominant soil type in the study area ( $95 \%)$ is (2) Gypsic Yermosols (Yy10-2/3a). It consists of a mixture of gravel, sand, silt, and clay. In comparison to the first soil type, its grain particles are smaller. It has a huge role and influence on runoff generation from precipitation. Both soil types were added to the SWAT model.

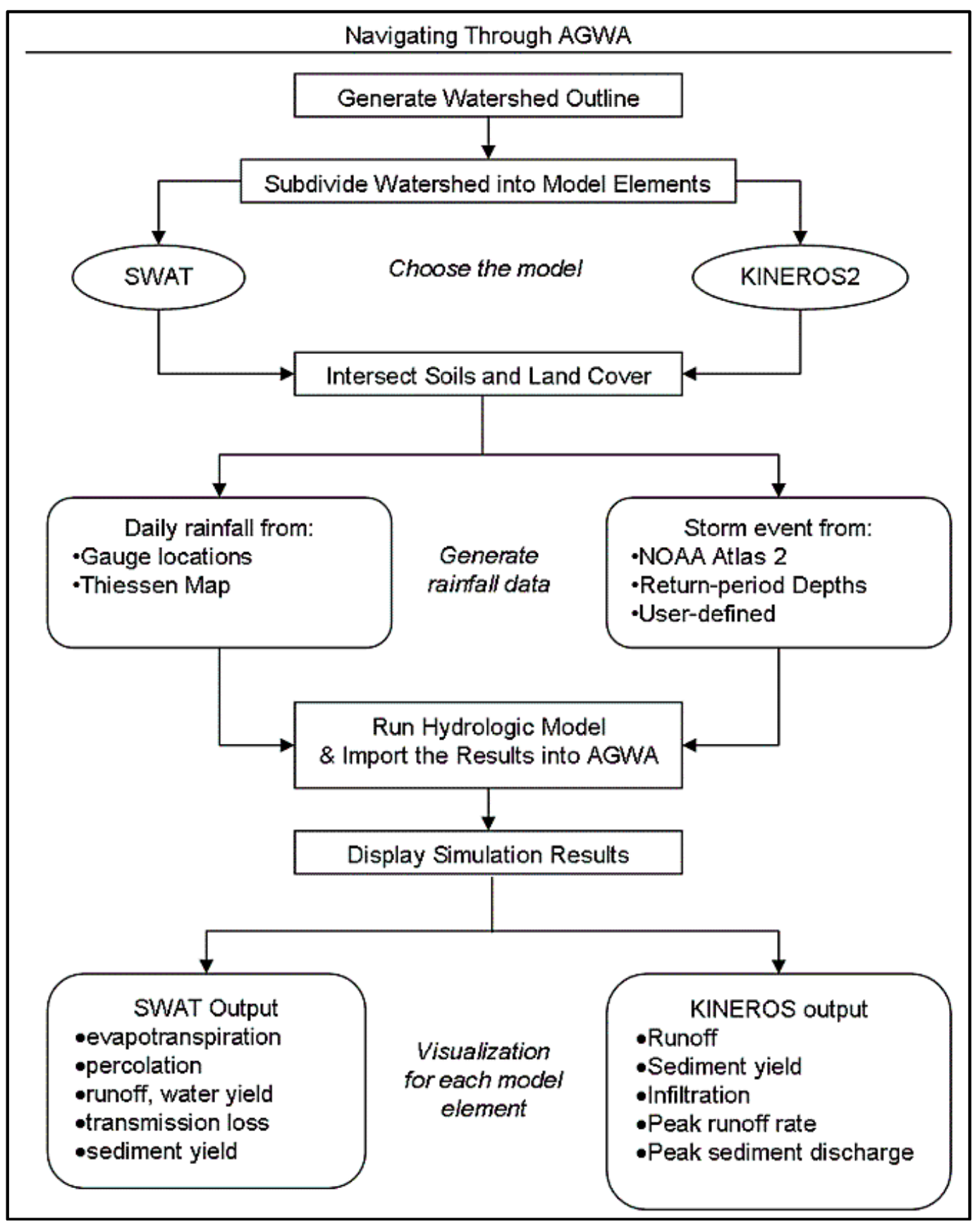

Fig. 2. Basic processing steps for AGWA2 (Burns et al., 2007). 
Table 1. Data used in the present study.

\begin{tabular}{|l|l|l|}
\hline \multicolumn{1}{|c|}{ Data } & \multicolumn{1}{c|}{ Source } & \multicolumn{1}{c|}{ Thematic Layer } \\
\hline Landsat 8 (OLI), April 2016 & USGS https://lpdaac.usgs.gov & Land use and land cover \\
\hline Soil Map & FAO & Soil Map \\
\hline Meteorological data & Kirkuk meteorological station & Precipitation map \\
\hline \multirow{4}{*}{ DEM } & \multirow{3}{*}{ USGS } & Watershed delineation \\
\cline { 3 - 4 } & & Drainage network \\
\cline { 3 - 4 } & & Slope \\
\cline { 3 - 4 } & & Elevation \\
\hline
\end{tabular}

* USGS is United States Geological Survey, FAO is Food and Agriculture Organization of the United Nations, and OLI is Operational Land Imager

According to Khoi \& Suetsugi (2014), the land use and land cover (LULC) map impact the hydrologic constituents of a basin, such as evaporation, transpiration, water flow, and groundwater recharge. In this study, a total of five LULC classes are considered. These are agricultural land or cropland (39\%), grassland (9\%), water or wetland $(2 \%)$, shrub $(1 \%)$, and barren land (49\%) (Figure 3a). It has been used to prepare the Curve Number (CN) map. In the SWAT model, the $\mathrm{CN}$ technique is used for calculating daily surface runoff as a function of soil permeability, LULC, and the content of previous 5-day soil moisture.

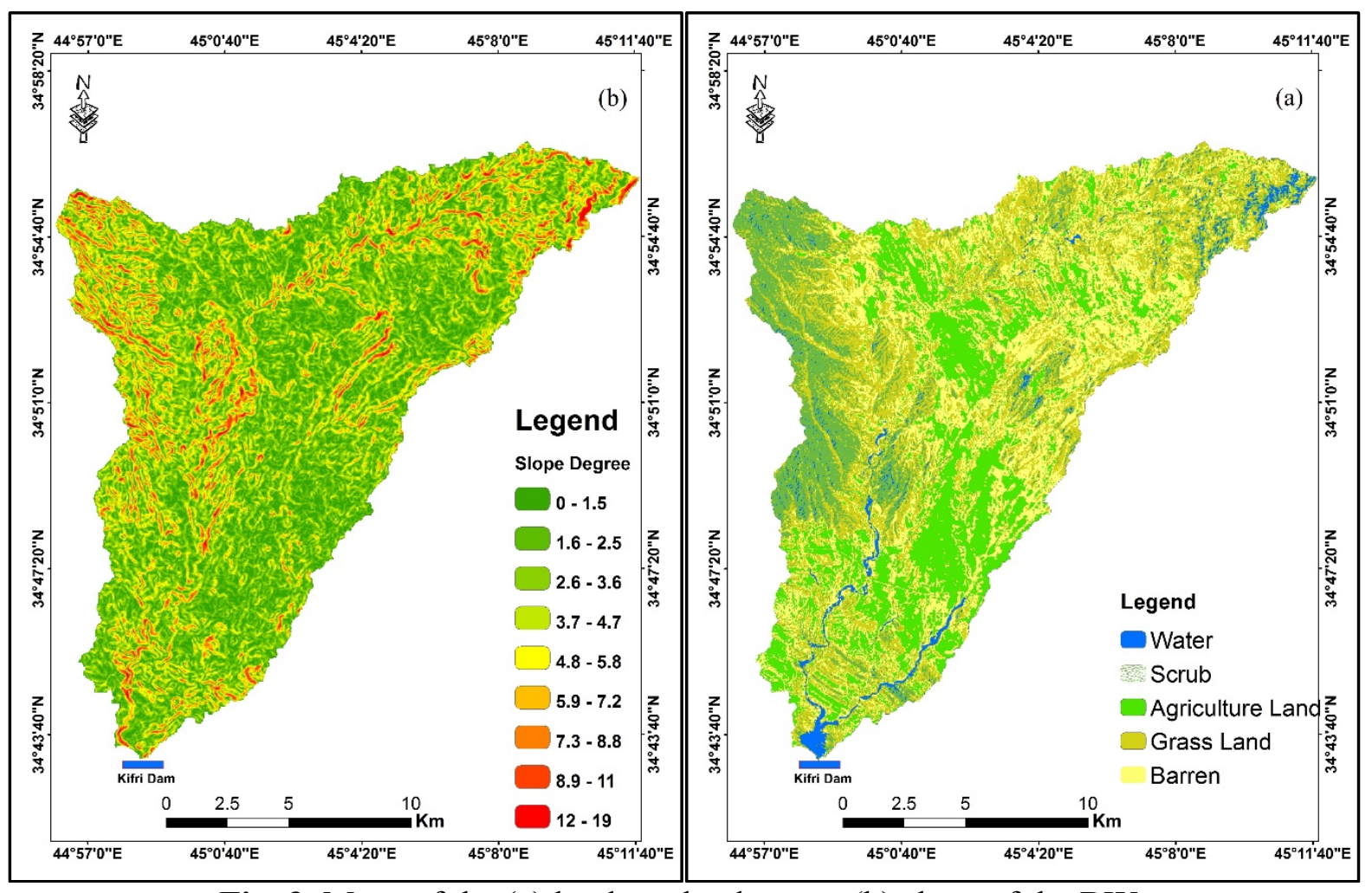

Fig. 3. Maps of the (a) land use land cover, (b) slope of the BW. 


\section{Results}

The precipitation data were entered into the model to obtain a final output map of precipitation for the entire watershed. The annual average rainfall is $347 \mathrm{~mm}$ for the past 30 years. The spatial distribution of evapotranspiration reveals the high rate at low slope areas in the eastern part of the watershed where the low flowing water velocity, cultivated land, and higher solar radiation occurs (Figure 4b). It is categorized into three classes (low, moderate, and high).

The percolation is the downward movement of surface water to subsurface water calculated in the current study depending on the SWAT model. Similar to evapotranspiration, the spatial distribution of percolation shows low-rate values $(12.4-22.1 \mathrm{~mm})$. It lies along the western part of the watershed, while the moderate percolation values $(22.1-27.6 \mathrm{~mm})$ spread in variance locations in the watershed. Whereas the high rate of percolation values (27.6 - 33.7 $\mathrm{mm}$ ) is distributed at a low slope area in the eastern and middle parts of the watershed (Figure 5a). The low slope gradient areas give more time for flowing water to percolate through soil layers.

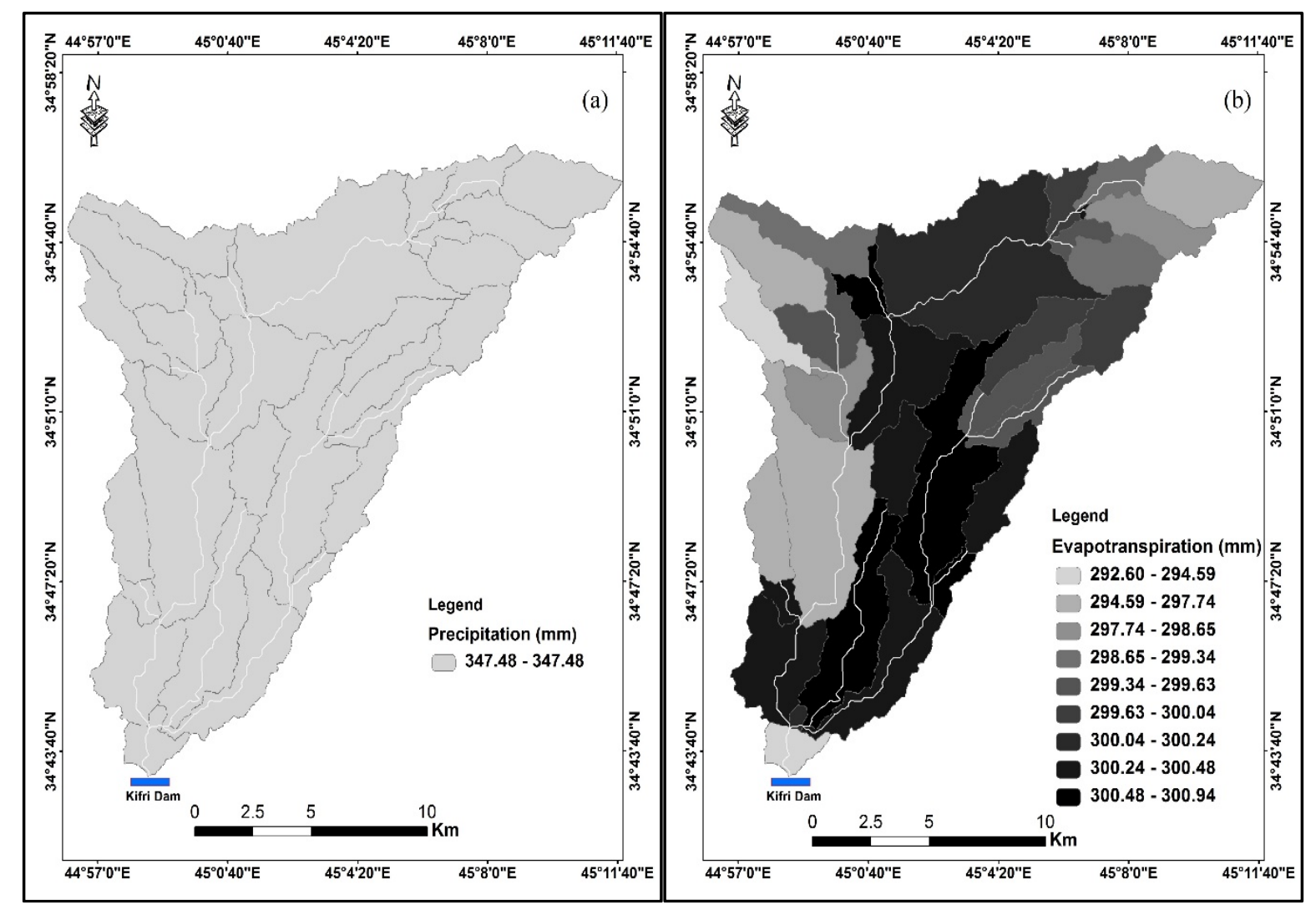

Fig. 4. Maps of the (a) precipitation, (b) evapotranspiration of the BW.

The channel discharge is the capacity of the stream valleys to drain accumulated water. It increases with the increase of stream order. The low channel discharge (88000 - 267000 $\mathrm{m}^{3}$.day $\left.{ }^{-1}\right)$ is located at the uppermost drainage divide and the moderate one (267000- 777400 $\mathrm{m}^{3}$. day $\left.{ }^{-1}\right)$ is located along the eastern channel branch in the watershed. The highest value of channel discharge $\left(777400-5,125,250 \mathrm{~m}^{3}\right.$. day $\left.^{-1}\right)$ is situated at the outlet of the watershed (Figure $5 \mathrm{~b}$ ). The mainstream branch in the western part contributes to channel discharge more than the mainstream branch in the eastern part. 


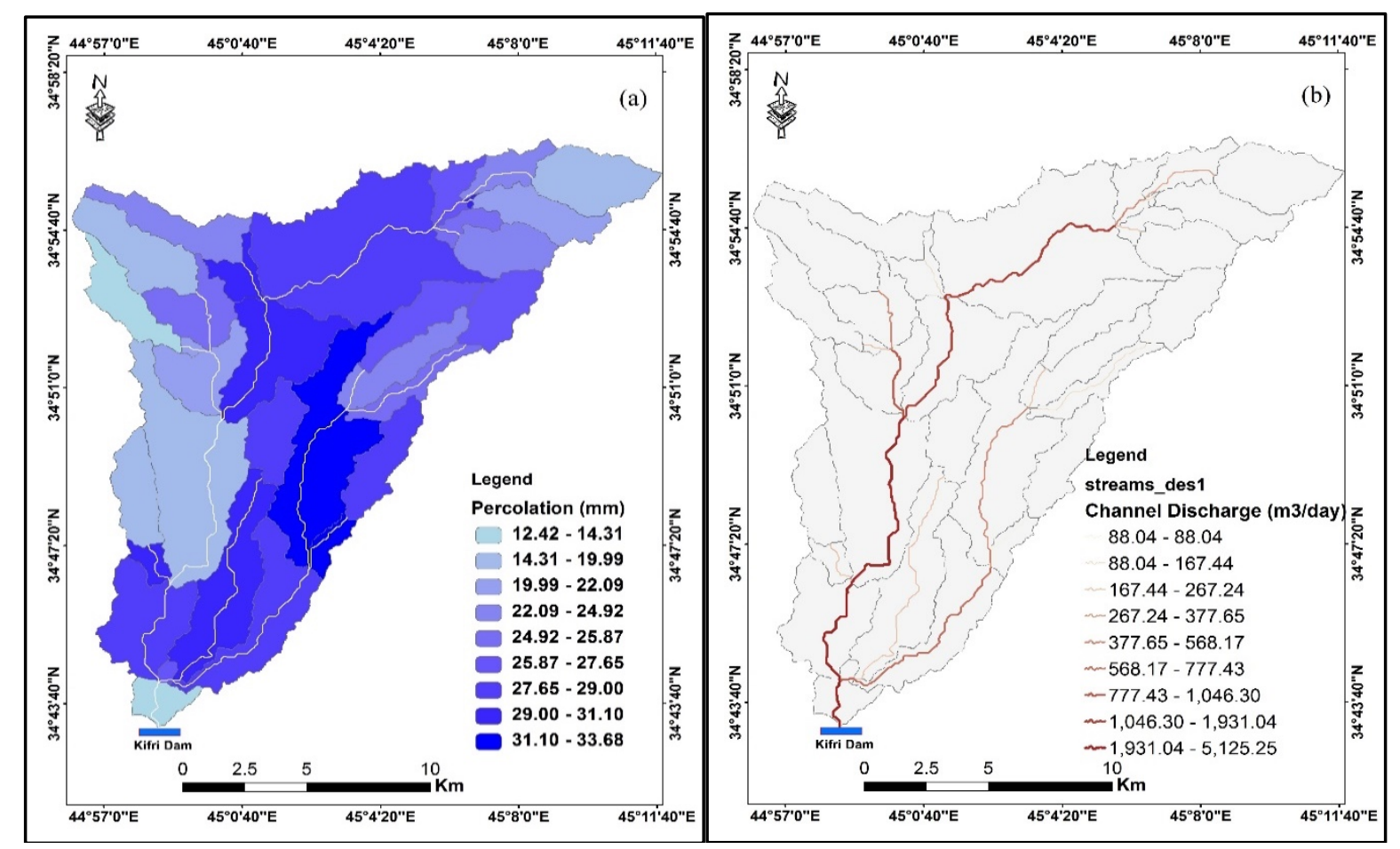

Fig. 5. Maps of the (a) percolation, (b) channel discharge of the BW.

The surface runoff is produced when rainfall intensity exceeds the infiltration rate of the soil and moves down to the channel stream. SCS and Green Ampt. methods are used for calculating surface runoff in the SWAT model (Kishor et al., 2016). The low surface runoff $(10.3-15.9$ $\mathrm{mm})$ dwells in the eastern and southern parts. The moderate surface runoff $(15.9-21 \mathrm{~mm})$ occupies the middle parts, while the high value of surface runoff $(21-39.3 \mathrm{~mm})$ resides in the northern and western parts of the watershed (Figure 6a).

The water yield represents the net precipitation subtracted from the losses (evapotranspiration, percolation and interception). The high value of channel water yield (7.8 $-11.9 \mathrm{~mm}$ ) locates along the western part, and the uppermost eastern part, while the low and moderate values of channel water yield $(3.3-7.8 \mathrm{~mm})$ locate at the middle and eastern parts of the watershed. There is a great resemblance in the spatial allocation of the channel and subwatershed water yield. The low and moderate values of sub-watershed water yield $(1.2-7.5$ $\mathrm{mm})$ locate in the middle and eastern parts of the watershed, while the highest values $(7.5-$ $13.5 \mathrm{~mm}$ ) locates in the northern and uppermost eastern parts of the study area (Figure 6b). It coincides with the spatial distribution of the surface.

The water yield capacity is high at very low to moderate density grassland, while it is less at the agriculture or farmland. As a result, the concentration of water yields high in stream channels within the sub-watersheds at northern and western parts of the watershed. As a result, the northern and western parts of the study area expose to denudational processes more than the other parts.

The water transmission losses or intakes because of ex-/infiltration into/from recent aquifers along river stretches (Bronstert et al., 2014). The high value of channel transmission losses $\left(0.01-0.03 \mathrm{~m}^{3} . \mathrm{s}^{-1}\right)$ resides in the western and uppermost eastern parts of the watershed. In contrast, the low and moderate values of channel transmission losses locate in the middle and the eastern parts of the watershed. As a result, the low and moderate values of sub- 
watershed transmission losses $(8.5-15.6 \mathrm{~mm})$ locate in the middle and eastern parts of the watershed, while the highest value $(15.6-27.1 \mathrm{~mm})$ locates at the western and uppermost eastern parts of the study area (Figure 7a).

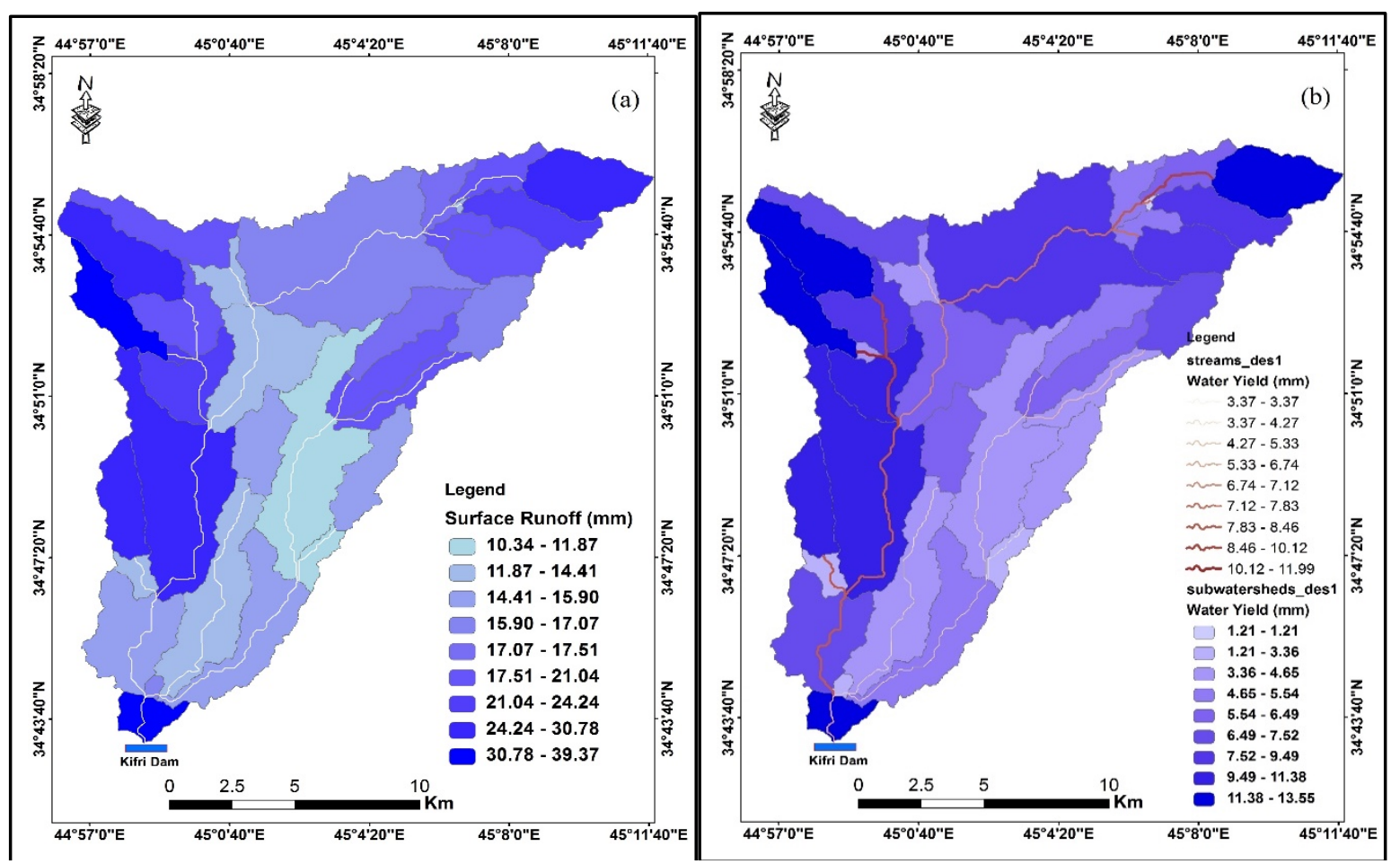

Fig. 6. Maps of the (a) surface runoff and (b) water yield of the BW.

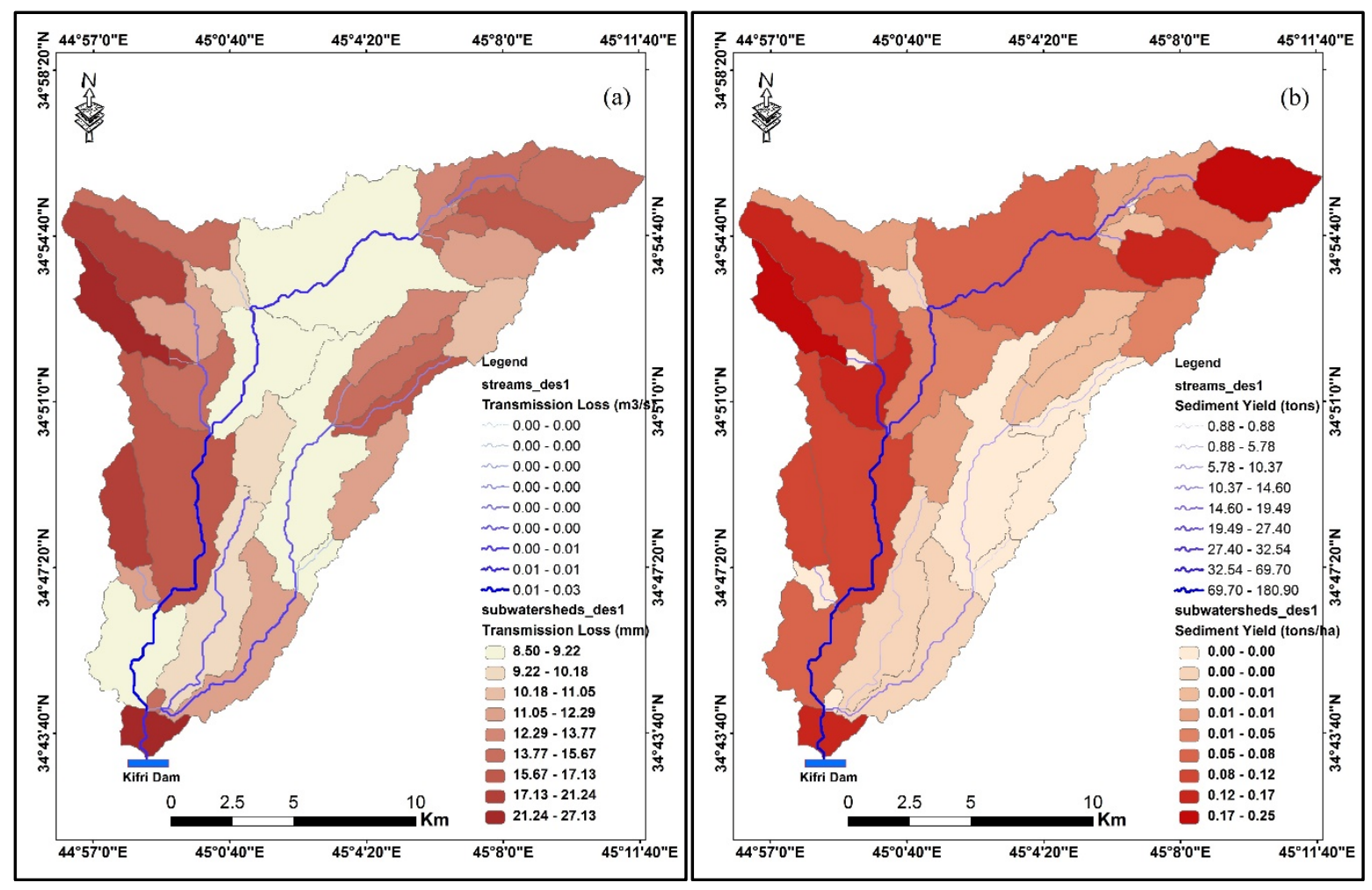

Fig. 7. Spatial distribution of (a) transmission losses and (b) sediment yield of the BW. 
The spatial distribution of stream channel and sub-watershed sediment yield shows similarity with the spatial distribution of channel discharge (Figure $7 \mathrm{~b}$ ). The channel sediment yield at the western and the uppermost parts delivers high sediment rates (27.4 - 180.9 tons). Similar to that, the sub-watershed at the western and the uppermost parts generate a high sediment rate $\left(0.08-0.25\right.$ tons. $\left.\mathrm{ha}^{-1}\right)$ in comparison to sub-watershed sediment yield in the middle and eastern parts, where they were low and moderate $\left(0.0-0.08\right.$ tons.ha $\left.^{-1}\right)$.

\section{Discussion}

The spatial distribution of output parameters shows visible variation all over the study area. The high values of evapotranspiration, percolation and transmission losses appear in the eastern and middle parts of the watershed. The main reason is due to relatively flat topography characteristics (slope gradient and elevation), low orographic precipitation, soil accumulation, and crop with grassland use and cover at eastern and middle part in comparison to other parts that lowering down water velocity, giving more time for evapotranspiration, water percolation, and transmission losses. In contrast to that, the western and uppermost northeastern parts are characterized by low evapotranspiration rate, low water percolation, low transmission losses, high channel discharge, high surface runoff, high water yield, and sediment yield due to high topographic relief, bare and cultivate land cover, and high precipitation rate. According to AlKubaisi \& Salar (2009), the northern and western parts are occupied by less permeable bedrocks of Injana and Muqdadiyah formations. In other words, it is recognizable that the areas corresponding with high rates of sediment yield are closely related to the lithology, steep slope, and highly elevated areas and vice versa. Topographic characteristics are directly proportional to soil erosion and sediment yield (Magesh \& Chandrasekar, 2016). According to Mosbahi et al. (2012), the exposed soils are characterizing by high runoff, permitting less residence time to rainfall for percolation and subsequently causing high erosion rates. The low vegetation cover in agricultural lands intensifies soil erosion in these areas (Mhangara et al., 2012). Salar (2013) stated that the steep slope, high elevation, and high precipitation rate are generating high fluvial erosional power that accelerating soil erosion and sediment yield by Hortonian overland flow and high stream discharges. In addition to soil types, lithology affects erosion processes and sediment yield. The study area is completely cover by clastic sedimentary rocks of Fatha, Injana, Mukdadiyah, Bai Hassan formations with Quaternary sediments (Al-Umary et al., 2013). Lithology is influencing the speed of erosional processes (Ali et al., 2016). The coarse-grained and highly permeable bedrocks of Bai Hassan Formation and Quaternary sediments occupy the middle and eastern parts of the watershed. Based on (Meghdadi, 2013), erodibility is decreasing with increasing infiltration rates and permeability. Hence, the Umarbil - Hazarkani mainstream branch, at the western and northern parts of the watershed, contributes more water and sediment yield to the BD at the watershed outlet than the Fatahumar Bakrashal mainstream branch. The sediment flux impacted the reservoir's life span, reservoir capacity, and the town's fate. Thus, this problem needs a serious solution. Most of the 
solutional projects must reside on Umarbil - Hazarkani mainstream branch for reducing flowing water velocity and enabling more sediment deposition before reaching the dam's lake. This kind of study improves sustaining development strategies and water resources management in the watersheds as a part of natural resources management and planning with the assistance of the SWAT model. One of the aims of using the SWAT model is watershed management and planning processes (Biru \& Kumar, 2017). The sediment yield map shows the spatial distribution of sediment productive areas in the BW, which represents the best spatial distribution of the ground surface degradation problems. It reflects poor planning and managing natural resources and watersheds. In contrast to that, the sediment yield map facilitates practicing the best solutions to mitigate and minimize the size of the ground surface degradation problems all over the study area. Shukla \& Gedam (2018) with Salar (2019) stated that knowing the hydrological components of a river basin help decision-makers to develop natural resources management such as water. Land management, soil information, and climatic situations of the watershed are essential for comprehensive understanding and assessment of hydrological processes, which help to decrease the highest rate of runoff that producing soil erosion (Dutta \& Sen, 2017). The finest management and planning for the BW are mitigating and minimizing the size of the ground surface degradation problems all over the study area with increasing the lifespan of the BD depending on the results and output parameters of the SWAT model that identify the potential areas for water and sediment yield. This can be operated by (1) fixing soil by plantation processes and (2) building supplementary water harvesting, and sediment trap projects across the potential branches for reducing runoff velocity. Meghdadi (2013) states that the rate of stream load can be minimized by building low-cost structures such as filter fences and check dams.

\section{Validation}

In the present study, the validation of the results was based on field observations on October 27 and 28, 2015, due to the absence of field measured data for water and sediment yield. On that date, the BD was subjected to real problems and risks. This Two-day storm ( $84 \mathrm{~mm})$ caused the closure of the dam's gate by huge sediment loads at the bottom of the dam body carried by the stream branches at the upper reaches of the watershed. The spillway of the dam could not drain the excess water (Figure 8). As a result, the actual hazard was produced on the dam's body and Kifri town. Overwhelming rainfall can have a great influence on the environment and human life (Amiri \& Mesgari, 2018). Hence, to minimize the pressure on the dam's body, the spillway had been expanded and enlarged to accommodate such a huge storm. The short duration and more intense precipitation mean more water flow and less water percolation, mainly at the onset of the wet season (Yasin \& Clemente, 2014). This unexpected storm was an alarm and motivation to study the hydrologic behavior of the BW for reaching the best water management. 

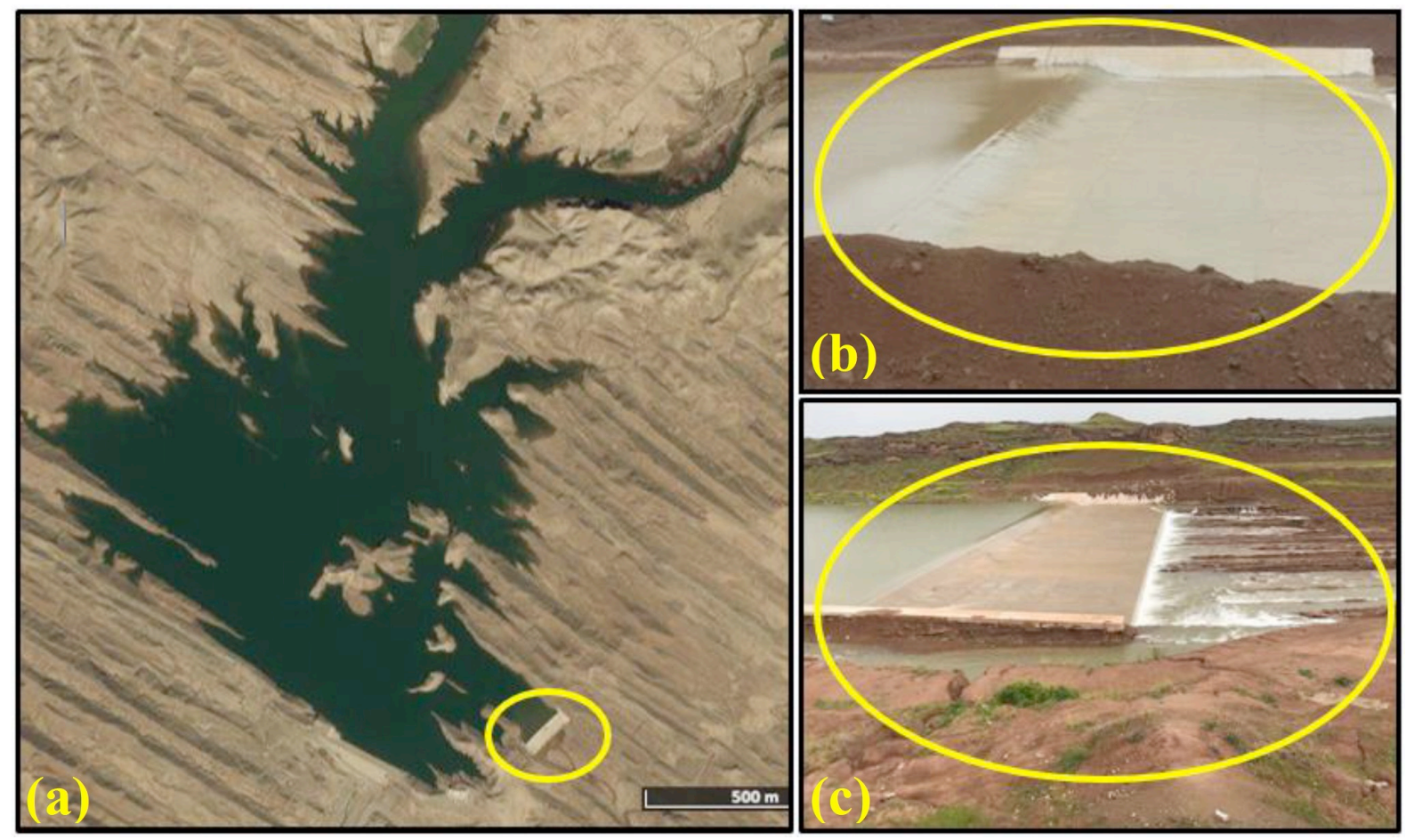

Fig. 8. Spillway of the BD before Oct. 27 and 28, 2015 (b) and after Oct. 27 and 28,2015 (c).

\section{Conclusions}

Soil erosion and sediment deposition are serious problems facing the Bawashaswar reservoir, which arising from ground surface degradation in the BW. The present study aimed to estimate water and sediment yield in the BW utilizing the SWAT model to integrate ArcGIS and remote sensing techniques. The SWAT model is a robust tool for predicting soil erosion and sediment flux, especially in the ungauged watershed.

The analysis of the results demonstrated the heterogeneous spatial distribution of evapotranspiration, transmission losses, percolation, surface runoff, channel discharge, water, and sediment yield in sub-watersheds are reflecting the spatial variations of precipitation, soil types, land use, topography, and geology as influencing factors. All sub-watersheds do not similarly contribute to water flow and sediment deposition. Umarbil - Hazarkani mainstream branch, at the western and the northern parts of the watershed, contribute more water and sediment yield to the BD than Fatahumar - Bakrashal mainstream. The evapotranspiration, percolation and transmission losses show high values at the eastern and the middle parts of the watershed, in contrast to the western and the uppermost northeastern parts, which are characterized by low evapotranspiration rate, low water percolation, low transmission losses, high channel discharge, high surface runoff, high water, and sediment yield. The sediment flux impacted the reservoir's life span, reservoir capacity, and the town's fate. Thus, this problem needs a serious solution. Most of the solutional projects must reside on Umarbil - Hazarkani

mainstream branch to reduce flowing water velocity and enable more sediment deposition before reaching the dam's lake. 


\section{References}

Afshar, A. A., \& Hassanzadeh, Y. (2017). Determination of Monthly Hydrological Erosion Severity and Runoff in Torogh Dam Watershed Basin Using SWAT and WEPP Models. Iranian Journal of Science and Technology, Transactions of Civil Engineering. https://doi.org/10.1007/s40996-017-0056-1

Al-Kubaisi, Q. Y., \& Salar, S. G. (2009). Hydrochemical Evaluation of the Groundwater in Fatah Umar - Hazar Kani Area, Northeast Iraq. Iraqi Bulletin of Geology and Mining, 5(1), 87-99.

Al-Umary, F. A.-W., Ali, S. S., \& Salar, S. G. (2013). Identification of Flood Prone and Water Conservation Areas In Sarqala Watershed Using Remote Sensing and GIS, Kurdistan Region Iraq. Garmyan University Journal, 2, 29-56.

Alipour, M., \& Hosseini, M. (2018). Simulation of surface runoff in Karaj dam basin, Iran. Applied Water Science, 8(147), 1-10. https://doi.org/10.1007/s13201-018-0782-y

Amin, H., Khan, M., \& Ajmal, M. (2019). Dynamics of gabion weirs and its comparison to reinforced concrete weirs. Kuwait Journal of Science, 46(2), 94-103.

Amiri, M. A., \& Mesgari, M. S. (2018). Analyzing the spatial variability of precipitation extremes along longitude and latitude, northwest Iran. Kuwait Journal of Science, 45(1), 121 127.

Asl-Rousta, B., Mousavi, S. J., Ehtiat, M., \& Ahmadi, M. (2018). SWAT-Based Hydrological Modelling Using Model Selection Criteria. Water Resour Manage. https://doi.org/10.1007/s11269-018-1925-5

Biru, Z., \& Kumar, D. (2017). Calibration and validation of SWAT model using stream flow and sediment load for Mojo watershed, Ethiopia. Sustainable Water Resources Management. https://doi.org/10.1007/s40899-017-0189-1

Bronstert, A., de Araújo, J. C., Batalla, R. J., Costa, A. C., Delgado, J. M., Francke, T., Vericat, D. (2014). Process-based modelling of erosion, sediment transport and reservoir siltation in mesoscale semi-arid catchments. Journal of Soils and Sediments, 14(12), 20012018. https://doi.org/10.1007/s11368-014-0994-1

Burns I. S., Scott S. N., Levick L. R., Semmens D., Miller S. N., Hernandez M., Goodrich D. C., K. W. G. (2007). Automated Geospatial Watershed Assessment ( $A G W A$ ): Documentation. Tuscon, Arizona: United States Department of Agriculture, Agricultural Research Service.

Chowdary, V. M., Chakraborthy, D., Jeyaram, A., Murthy, Y. V. N. K., Sharma, J. R., \& Dadhwal, V. K. (2013). Multi-Criteria Decision Making Approach for Watershed Prioritization Using Analytic Hierarchy Process Technique and GIS. Water Resour Manage, 3555-3571. https://doi.org/10.1007/s11269-013-0364-6

Duan, W., He, B., Takara, K., Luo, P., Nover, D., \& Hu, M. (2017). Impacts of climate change on the hydro-climatology of the upper Ishikari river basin, Japan. Environmental Earth Sciences, 76(490), 1-16. https://doi.org/10.1007/s12665-017-6805-4 
Dutta, S., \& Sen, D. (2017). Application of SWAT model for predicting soil erosion and sediment yield. Sustainable Water Resources Management. https://doi.org/10.1007/ s40899-017-0127-2

Fallah, M., Kavian, A., \& Omidvar, E. (2016). Watershed prioritization in order to implement soil and water conservation practices. Environmental Earth Sciences. https://doi.org/10.1007/s12665-016-6035-1

FAO-Unesco. (2007). Digit al Soil Map of the World.

Kavian, A., Golshan, M., \& Abdollahi, Z. (2017). Flow discharge simulation based on land use change predictions. Environmental Earth Sciences, 76(588), 1-17. https://doi.org/10.1007/s12665-017-6906-0

Khoi, D. N., \& Suetsugi, T. (2014). Impact of climate and land-use changes on hydrological processes and sediment yield - a case study of the Be River catchment, Vietnam. Hydrological Sciences Journal, 59(5), 1095-1108. https://doi.org/10.1080/02626667.2013.819433

Kishor, B., Gosain, P. A. K., Paul, G., \& Khare, D. (2016). Climate change impact assessment on hydrology of a small watershed using semi-distributed model. Applied Water Science. https://doi.org/10.1007/s13201-016-0383-6

Krishnan, N., Raj, C., Chaubey, I., \& Sudheer, K. P. (2018). Parameter estimation of SWAT and quantification of consequent confidence bands of model simulations. Environmental Earth Sciences, 77(470), 1-16. https://doi.org/10.1007/s12665-018-7619-8

Krysanova, V., \& White, M. (2015). Advances in water resources assessment with SWATan overview. Hydrological Sciences Journal, 60(5), 771-783.

Liu, Y., Yang, W., Yu, Z., Lung, I., \& Gharabaghi, B. (2015). Estimating Sediment Yield from Upland and Channel Erosion at A Watershed Scale Using SWAT. Water Resour Manage. https://doi.org/10.1007/s11269-014-0729-5

Magesh, N. S., \& Chandrasekar, N. (2016). Assessment of soil erosion and sediment yield in the Tamiraparani sub-basin, South India, using an automated RUSLE-SY model. Environmental Earth Sciences, 75(16). https://doi.org/10.1007/s12665-016-6010-x

Meghdadi, A. R. (2013). Identification of effective best management practices in sediment yield diminution using GeoWEPP : the Kasilian watershed case study. Environ Monit Assess. https://doi.org/10.1007/s10661-013-3293-1

Mhangara, P., Kakembo, V., \& Lim, K. J. (2012). Soil erosion risk assessment of the Keiskamma catchment, South Africa using GIS and remote sensing. Environ Earth Sci, 65, 2087-2102. https://doi.org/10.1007/s12665-011-1190-x

Mosbahi, M., Benabdallah, S., \& Boussema, M. R. (2012). Assessment of soil erosion risk using SWAT model. Arab J Geosci. https://doi.org/10.1007/s12517-012-0658-7 
Mukundan, R., \& Pierson, D. C. (2015). Using detailed monitoring data to simulate spatial sediment loading in a watershed. EnvironMonit Assess, 187(532), 1-10. https://doi.org/10.1007/s10661-015-4751-8

Othman, A. A., Gloaguen, R., Andreani, L., \& Rahnama, M. (2018). Improving landslide susceptibility mapping using morphometric features in the Mawat area, Kurdistan Region, NE Iraq: Comparison of different statistical models. Geomorphology, 319, 147-160. https://doi.org/https://doi.org/10.1016/j.geomorph.2018.07.018

Othman, A. A., \& Gloaguen, R. (2013). Automatic extraction and size distribution of landslides in Kurdistan Region, NE Iraq. Remote Sensing, 5(5), 2389-2410. https://doi.org/10.3390/rs5052389

Othman, A. A., \& Gloaguen, R. (2014). Improving lithological mapping by SVM classification of spectral and morphological features: The discovery of a new chromite body in the Mawat ophiolite complex (Kurdistan, NE Iraq). Remote Sensing, 6(8), 6867-6896. https://doi.org/10.3390/rs6086867

Othman, A. A., Obaid, A. K., Al-ManmI, D. A. M. A., Al-Maamar, A. F., Hasan, S. E., Liesenberg, V., Al-Saady, Y. I. (2021). New Insight on Soil Loss Estimation in the Northwestern Region of the Zagros Fold and Thrust Belt. ISPRS Int. J. Geo-Inf, 10(2), 59. https://doi.org/10.3390/ijgi10020059

Othman A.A., Al-Maamar A.F., Al-Manmi D.A.M., Liesenberg V., Hasan S.E., Al-Saady Y.I., S. A. T. and K. K. (2019). Application of DInSAR-PSI Technology for Deformation Monitoring of the Mosul Dam, Iraq. Remote Sensing, 11(22), 2632. https://doi.org/10.3390/rs11222632

Salar, S. G. (2006). Hydrogeology and Hydrogeochemistry of Kifri Area/ North of Iraq. M. Sc. Thesis, College of Science, University of Baghdad.

Salar, S. G. (2009). Hydrogeomorphology of Bawashaswar watershed in Northeast of Iraq. Journal of Kirkuk University Humanity Studies, 4(2), 61-79.

Salar, S. G. (2013). Geomorphic Analysis for Water Harvesting Using GIS Technique in Selected Basins/ Garmiyan Iraqi Kurdistan Region. University of Sulaimani.

Salar, S. G. (2019). Identification of Forest Fire Risk Zones in the Sartak Watershed, Kurdistan Region, Iraq: Gis and Remote Sensing Applications. Iraqi Bulletin of Geology and Mining, 15(1), 105-122.

Salar, S. G., Othman, A. A., \& Hasan, S. E. (2018). Identification of suitable sites for groundwater recharge in Awaspi watershed using GIS and remote sensing techniques. Environmental Earth Sciences, 77(19), 0. https://doi.org/10.1007/s12665-018-7887-3

Shukla, S., \& Gedam, S. (2018). Evaluating Hydrological Responses to Urbanization in a Tropical River Basin: A Water Resources Management Perspective. Natural Resources Research. https://doi.org/10.1007/s11053-018-9390-7 
Sissakian, V. K., \& Al-Jiburi, B. S. M. (2012). Stratigraphy of the High Folded Zone. Iraqi Bulletin of Geology and Mining, Special Is(5), 63-132.

Talebizadeh, M., Morid, S., Ayyoubzadeh, S. A., \& Ghasemzadeh, M. (2010). Uncertainty Analysis in Sediment Load Modeling Using ANN and SWAT Model. Water Resour Manage, 24, 1747-1761. https://doi.org/10.1007/s11269-009-9522-2

Wang, G., Mang, S., Cai, H., Liu, S., Zhang, Z., Wang, L., \& Innes, J. L. (2016). Integrated watershed management: evolution, development and emerging trends. Journal of Forestry Research, 27(5), 967-994.

Woznicki, S. A., \& Nejadhashemi, A. P. (2013). Spatial and Temporal Variabilities of Sediment Delivery Ratio, 2483-2499. https://doi.org/10.1007/s11269-013-0298-z

Yasin, H. Q., \& Clemente, R. S. (2014). Application of SWAT Model for Hydrologic and Water Quality Modeling in Thachin River Basin, Thailand. Arab J Sci Eng (2014), 39, 16711684. https://doi.org/10.1007/s13369-013-0770-3

Yesuf, H. M., Melesse, A. M., Zeleke, G., \& Alamirew, T. (2016). Streamflow prediction uncertainty analysis and verification of SWAT model in a tropical watershed. Environmental Earth Sciences, 75. https://doi.org/10.1007/s12665-016-5636-z

Yu, M., Chen, X., Li, L., Bao, A., \& Paix, M. J. de la. (2011). Streamflow Simulation by SWAT Using Different Precipitation Sources in Large Arid Basins with Scarce Raingauges. Water Resour Manage, 25, 2669-2681. https://doi.org/10.1007/s11269-011-9832-z

Submitted: $12 / 11 / 2020$

Revised: 11/02/2021

Accepted: 17/02/2021

DOI: $10.48129 /$ kjs.v49i1.11027 